Philosophical Books Vol. 50 No. 1 January 2009 pp. 79-86

\title{
CHRISTOPHER ROWE'S PLATO AND THE ART OF PHILOSOPHICAL WRITING
}

GEORGE RUDEBUSCH

Northern Arizona University

\section{Interpretation}

"The biggest question of all" in the book is "What is it, exactly, that Plato wanted to achieve, and thought he could achieve, by writing as he did?" (p. 2). As the book sees them, "Plato's texts ... force us to try to see whatever point it is that they are making through the fog of a conversation with this individual now" (p. 11).

The book begins its answer to the big question by making some uncontroversial claims about philosophical dialogue. The questing after truth-about how to live an excellent human life - is, according to the book, true philosophy: "Philosophy, as an activity, is the "art of dialogue" ... on the sorts of subjects expertise in which contributes to wisdom" (p. 8). The book identifies this art of dialogue in order to distinguish it from rhetorical persuasion.

For the book, it is reasonable to suppose that "the dialogues... have a persuasive function ... in addition to any purely philosophical one" (p. 12). The book distinguishes the persuasive function of rhetoric from the philosophical function of dialectic. As I interpret the book, The Art of Philosophical Writing, ${ }^{1}$ the art that is the topic of the book is not philosophical dialectic but persuasive rhetoric.

The book's point in drawing a distinction between philosophical dialogue and persuasive rhetoric is that in the case of Plato's dialogues "the philosophical will be employed in the service of the persuasive" (p. 12). Philosophical writing employs philosophical dialogue in the service of persuasive rhetoric. The subordination of philosophy to rhetoric justifies the book's claim that, in the case of Plato, "written dialogue is something considerably more than a piece of philosophy" (p. 10) and also justifies its claim that the fact that Plato "employed dialogue form in different ways, some of them not portraying dialectic in action, does not . . . indicate that he ever abandoned his view that living dialogue, based on questioning of oneself or others ... was the only available means to intellectual progress" (p. 10).

The big question was, "What was Plato's goal in writing as he did?" As I interpret the book, the big answer - I take this to be the main thesis of the book - is that Plato's writing is an art of persuasive rhetoric, employing in its service philosophical dialogue. And the goal of the rhetoric is to persuade readers to turn to a life in which they seek wisdom about human excellence through philosophical dialogue.

1. C. Rowe, The Art of Philosophical Writing $(\bullet \bullet, \bullet \bullet)$. 
It is a consequence of the book's big answer that it can defend a Unitarian thesis about Plato's philosophical career, despite the sharp contrasts in the style and content of Plato's dialogues. These contrasts seem to corroborate Aristotle's view that the character Socrates in the dialogues is sometimes a historical portrait, while at other times merely a mouthpiece for Plato's own views. The book's big answer allows it to explain why sharp contrasts in style and content need not correspond to a sharp contrast in Plato's philosophical career. Indeed, the bulk of the book is devoted to giving such explanations for a number of Plato's dialogues.

In style, for example, the book recognizes an appearance of sharp contrast between Socratic dialogues (full of mostly unsuccessful search) and non-Socratic dialogues (full of mostly successful answer). Here is the book's explanation: "What the situation in the "non-Socratic" ... dialogues marks is a change of strategy, not a change of mind. If Plato writes in a different way, that is because he has decided to approach his readers . . . by a different route . . Even while insisting that philosophy is the key, he by no means always uses dialectic or the written counterpart of dialectic to achieve that stimulation and provocation. In fact philosophical dialectic is merely one of his tools" (p. 13).

Coining my own terms for a distinction the book draws, I call the book's Plato a weak intellectualist throughout his Unitarian career. A strong intellectualist dismisses the tripartite soul as "mere illusion" (p. 170). In contrast, the weak intellectualist is an intellectualist about "what the soul really is"- -but that soul is "hidden" in "what it actually becomes, in [embodied] life" (p. 170). Being "made up of ... three parts... isn't how the soul really is, in its essential ("truest") nature" (pp. 170-1). But tripartite is what the soul actually becomes, whenever people "choose to go that way. Appetite may be a monster, but in itself . . . it is only a potential monster" (p. 172). Plato as a weak intellectualist finds himself sometimes addressing souls who have not achieved their truest nature and have monstrously overpowering appetites. He can use one genre of writing - dialectic - for the intellects of such people, while using other genres involving myths or graphic images - for their spirits, so that such souls as a whole can begin to move toward harmony by taming their appetites. ${ }^{2}$

In the substance of Plato's dialogues, the book recognizes a sharp contrast between, on the one hand, for example, the apparent intellectualism of some dialogues, which argue as if human excellence is nothing but knowledge how to live well, and on the other hand, the apparent nonintellectualism of other dialogues, in which the soul has three parts and in which knowledge is not enough for an excellent life, dialogues where virtues of character are required in addition to virtue of intellect. The general form of the book's explanation for this and other substantial contrasts in the dialogues is that when Plato portrays dialectic in action, such as the conversations with Polus or Thrasymachus, Socrates begins with different starting points appropriate to different interlocutors, and in such dialectic, different starting points compel different conclusions.

For example, about "the political and psychological analyses conducted in Republic 4," the book says, "there is a question mark over the level of Socrates'

2. See my "Swan Songs, Last Words and Myth's Aim," Thomist, 56 (1992), pp. 726-32. 
(and Plato's) commitment to [the conclusions, because] ... the argument is itself shaped as much by the interlocutors' assumptions and starting-points as by his own. Left to himself . . . Socrates makes quite clear [that] he would have rather different things to say about the best kind of city and the best state of the soul" (p. 17).

\section{First Evaluation: Small and Big Questions}

The book says that "for anyone who has seriously read any ... dialogue from beginning to end," "the biggest question of all" is "What is it, exactly, that Plato wanted to achieve . . . by writing as he did?" (p. 2). This is a meta-question, an academic question. In my judgment, there are much bigger questions for the serious reader. For example, there is the existential question Callicles asks in the Gorgias. Socrates has just concluded his argument with Polus: "To do wrong to another and get away with it, unpunished, is the worst thing that can happen to a man" (p. 479d). Upon hearing this, Callicles appropriately replies: "Socrates, if what you say turns out to be true, aren't we human beings living our lives upside down and doing everything quite the opposite of what we ought?" I agree with Callicles: everything important in human life hangs on the question whether Socrates' arguments are sound - not on the biographical question: "What were Plato's goals when he wrote the dialogues?" In my judgment, the book's scale of measurement about what is big and small for a serious reader needs to be turned upside down: Existential questions are big and authorial intent is small.

\section{Second Evaluation: Inferior and Superior Answers}

In order to make my second evaluation, I need to make an observation about one advantage of Socratic conversation and to review the Divided Line.

According to the Oxford English Dictionary, "in classical Greek Drama, [stichomythia is] dialogue in alternate lines, employed in sharp disputation, and characterized by antithesis." As examples, there are the disputations between Haemon and Creon in Sophocles' Antigone and between Orestes and the Chorus in the trial scene of Aeschylus's Eumenides.

Socrates refers to the event that I call stichomythia in an extended sense in the Euthyphro - when "we get angry and hostile to each other because we disagree and are unable to arrive at a decision" (7c10-12). As Socrates says, this happens not about matters we know how to settle by counting, weighing, and measuring, but about "the righteous and unrighteous, praiseworthy and disgraceful, good and bad" (7dl-2).

Stichomythia about what is righteous, praiseworthy, and good remains a mark of our personal moral and shared political lives. For example, human beings lack the ability to weigh the competing values of autonomy and benevolence in a wide range of cases, leading to irresolvable disputes within a person or a family, such as: When should I cease to make life decisions for my teen-age children as their 
intellects become more and more fully formed? When should I begin to make decisions for my elderly parents, as their intellects become more and more disabled? We are likewise unable decisively to weigh such values in our national deliberations about such things as legislating minimum wages or sex workers or sweat shops or trade in human organs or payday loan companies. I take it that such stichomythia is the defining existential problem for human beings.

My observation is that the great existential advantage of Socratic conversation is that it solves the problem of stichomythia. Socrates does not oppose point with counterpoint. He does not oppose at all. He merely asks questions. The interlocutor does not find himself making speeches opposed to rival speeches by Socrates. Instead, the interlocutor finds that stichomythia is replaced by self-examination, Socratically assisted.

I turn now to the Divided Line. As human beings, we seek answers to questions of the form What is $X$ ? such as What is the large? or What is a finger? There are two main kinds of answer: ostensive and discursive.

Ostensive - that is, visible - answers work by pointing out particular instances of what is large, like this building or this room. There is a problem with ostension. Particular instances of what is large will inevitably also be instances of, say, crowded or empty, well or poorly lit, warm or cold, and many other things that are not large. Worse, particular instances of large will inevitably also be, in some respects, small. Because of their multifaceted and even contrary nature, visible instances are ambiguous and relatively unclear answers to questions.

In contrast to ostensive answers, discursive answers draw attention to intelligible, not visible objects - these are Plato's Forms. By doing so, discursive answers avoid the unclarity of being ambiguous and contrary. Relative to visible instances, intelligible general accounts give us single-faceted hence unambiguous and hence relatively clear answers.

In the Republic, ${ }^{3}$ Socrates divides an imaginary line in proportion to the relative "clarity and obscurity" (509d9) of these different kinds of answers. The main division he makes on the line of more and less clear gives us a ratio of intelligible, discursive answers to visible, ostensive answers. Then, Socrates subdivides the two main parts.

There is a subdivision of the visible, between visible images and the things of which they are images. For example, take the question: What is Socratic dialogue? One kind of answer points out a visible image of Socratic dialogue, say, a printed Platonic text. While such a text is a kind of ostensive definition, Socrates says that there is another, clearer kind of visible answer. It is to show the questioners - to use my example - a living Socratic conversation by actually cross-examining them on the subject of human excellence. This living instance of Socratic dialogue belongs to the more clear subdivision of visible answers, while the written record of such a dialogue belongs to the less clear subdivision of visible answers.

In the same ratio of relative clarity and obscurity as the subdivisions of the visible, Socrates also subdivides the intelligible. The less clear subdivision of the intelligible proceeds down from hypotheses to conclusions - like Euclidean geometry

3. Plato, Republic $(\bullet, \bullet \bullet)$. 
$(510 \mathrm{c} 2,511 \mathrm{~b} 1)$ - while in the more clear subdivision, as the book translates, "Reason will "grasp" the uppermost of the four segments of the line "through its capacity for dialectic, treating its hypotheses not as [starting points, $\bullet \rho \chi \varsigma$ ] but actually as hypotheses, with the purpose [of] proceeding until it reaches the unhypothetical" answer, not working down to a conclusion but going up "to the starting point $(\bullet \rho \chi \bullet \vee)$ of the whole" (219) and only from that point going back down to a conclusion. ${ }^{4}$

Here, for example, is my hypothetical account in answer to the question, what is Socratic dialogue? Like Euclidean geometry, my answer sets out starting points from which it derives an account. Like Euclid, I allow myself five starting points:

- Nonphilosophers are blameworthy because they negligently act as if they know the ultimate human goods, while philosophers, seeking the wisdom they lack, are free from blame.

- Socrates' divine mission was to turn nonphilosophers into philosophers.

- Most people falsely think that the passions can overpower knowledge and hence falsely think that human excellence requires multiple character traits in addition to the single knowledge of human well-being.

- Socrates can refute most people who claim to know human excellence by getting them to take on a claim that excellence is multiple, then eliciting a contradiction.

- Socrates' refutations of such people are the best way to turn nonphilosophers into philosophers.

Given these five starting points, I can derive my account of Socratic dialogue. ${ }^{5} \mathrm{My}$ point here is that my account depends upon its starting points. If you accept contrary starting points, you will derive a contrary account of Socratic dialogue.

Many scholars do accept contrary starting points in their accounts of Socratic dialogue. My hypothetical answer does not have the resources to be reconciled with theirs, producing stichomythia. This stichomythia makes the truth of my hypothetical, Euclid-like answer unclear and illustrates how a hypothetical answer is an inferior intelligible answer. ${ }^{6}$ (Inferior hypothetical reasoning is not the method of hypothesis referred to in other dialogues. That method of hypothesis is a method for testing hypotheses, rather than taking them for granted and working down from them to conclusions.)

The superior intelligible answer is dialectic, which treats its hypotheses not as starting points but "actually as hypotheses, proceeding until it reaches the unhypothetical" answer (p. 219). ${ }^{7}$ If I am able to give this kind of dialectical answer, I would be able to begin with any starting points - in particular, the starting points of my interlocutor. Whenever the interlocutor gives a statement contrary to one of my postulates, I would elicit from that interlocutor other statements refuting his contrary statement.

4. Ibid., $511 \mathrm{~b} 4-8$.

5. See my Socrates (Wiley-Blackwell, 2009).

6. See Plato, Republic, 509d6-e1, 511a3-8.

7. Ibid., 511b5-7. 
Suppose, for example, that I meet someone who asserts a statement contrary to my third postulate of Socratic dialogue, that is, someone who states that the passions can overpower knowledge. If I am dialectical, I can begin from that contrary statement, and then elicit other statements that lead to contradiction. If I repeat this process often enough, eventually the interlocutor will have no alternative but accept my third postulate. And so, by dialectic, I am able, if I know my stuff, to lead interlocutors eventually to the truth of each of the five postulates from any statements they make contrary to those postulates. Thus, I am able to begin from any starting points yet reach, in the case of every interlocutor, the very same account of Socratic dialectic. This explains why, unlike the Euclidean kind of hypothetical answer, a dialectical answer is unhypothetical.

Let me sum up. A Euclidean answer can only work downward away from its starting points to a conclusion. A Euclidean answer is hypothetical and subject to stichomythia. In contrast, a dialectical answer is unhypothetical: It can begin from any starting points yet always produce agreement to the same answer. A dialectical answer is not caught in stichomythia. Thus, the dialectical is superior in clarity and truth to the hypothetical.

Let me emphasize: Hypothetical answers are not dialectic. Dialectic is better both for seeking the truth and for teaching the truth. It is better as a truthseeking strategy, because its results are not dependent upon possibly false starting points that go unchallenged. And it is better for persuading or teaching another the truth, because it begins with the interlocutor's assertions, even if they are contrary to the truth.

My interpretation of the Divided Line is one way to justify Plato's distinction between hypothetical and unhypothetical intelligibility. Very likely, my account is wrong, and there is a better way to interpret Plato's Divided Line. You do not need to accept my account as anything but provisional. I ask only that you accept that Plato does make a valid distinction between inferior hypothetical and superior unhypothetical answers, either according to the details of my interpretation or according to some better interpretation. (Notice, by the way, that the essay now in your hands is an inferior hypothetical answer: It is incapable of beginning from your starting points to reach my conclusion.) If you accept that Plato's distinction is valid, then you will also agree with my second evaluation of the book: The book fails to give an account of Plato's Art of Philosophical Writing. The book fails because its account of Socratic dialectic is antidialectical.

The book's confusion of the hypothetical method for unhypothetical dialectic is easy to document. Let me begin from the statement: "The exchange between Socrates and his interlocutors in the text of the Republic will itself count as a perfectly acceptable example of the kind of thing dialectic may be" (p. 167).

About Republic 1, the book says, "The real problem is that Socrates has been talking across rather than to Thrasymachus. [Socrates] may be satisfied with his own arguments, but he has done little or nothing to persuade his opponent; and indeed, insofar as he is - as I see it - using assumptions that Thrasymachus will never even have dreamed of sharing, one could say that he hasn't even tried" (p. 177). The features the book attributes to Socrates make his discourse, what the Divided Line calls, inferior hypothetical discourse. There is Socrates' use of starting points that Thrasymachus does not share ("will never even have 
dreamed of sharing") and the resulting stichomythia ("talking across rather than to Thrasymachus"). Yet, the book says that this discourse is a "perfectly acceptable example of the kind of thing dialectic may be." This is a confusion of hypothetical and dialectical discourse.

There is much more of the same confusion. The book says, "Socrates is using premisses which are perfectly familiar and true to him, but entirely unfamiliar to Thrasymachus, who if told what they were would reject them outright" (pp. 186-7). Not only must Socrates be using inferior hypothetical reasoning, he is apparently hiding the fact from Thrasymachus!

Again, the book says: 'It is true that this defence of Socrates' argument in one way leaves it looking even worse: not only is it rather a weak argument, but it doesn't really address Thrasymachus's position at all" (p. 193). With Thrasymachus, "Socrates at every turn begins from positions that he himself holds" (p. 195). Socrates' dialogue with Thrasymachus is an inconclusive "confrontation between two opposing perspectives" (p. 195). And "the outcome is that we, the readers, have two different arguments to choose from. If we opt for the one Thrasymachus goes along with, then we shall end up about as happy as Thrasymachus, i.e. not very happy. If on the other hand we opt for the argument that Socrates has in mind, and that uses [that is, works downward from] his premisses, then our degree of contentment will be in proportion to our contentment with the premisses" (pp. 186-7).

Curiously, the book seems to endorse the hypothetical method (which it confuses with dialectic) as a way to persuade someone who begins from contrary starting points: "Socrates starts from what he himself believes, and after all his ultimate aim is to bring Thrasymachus and anyone else around to his own point of view" (p. 189). The book seems unaware that the method it attributes to Socrates is inferior, that its hypothetical conclusions are obscure in comparison to the clarity of unhypothetical dialectic: "Since Socrates believes in his own premisses and disbelieves in Thrasymachus's ... this is a quite reasonable way for him - for Socrates - to go" (pp. 186-7). As I have documented above, the book sees that, in fact, stichomythia rather than persuasion is a feature of the hypothetical method it attributes to Socrates. So, I cannot tell why the book endorses discourse that takes for granted one's own starting points in conversation with someone who does not share them, and I could find no reasons anywhere in the book supporting the endorsement.

In my judgment, the Divided Line is right that to elicit the same position from any starting point is clearer and more persuasive than to be able only to work down to conclusions from hypotheses taken for granted. And so, the hypothetical method is an inferior way to persuade.

Let me say in passing that the book's repeated statements that Socrates uses assumptions in his argument without securing agreement to them are false. Certainly, Socrates does painstakingly work from Thrasymachus' own position. ${ }^{8}$ The book does not give a close reading of the arguments with

8. On 340d-345e, see my "Socratic Neutralism," in D. Cairns, F.-G. Herrmann, and T. Penner (eds.), The Good and the Form of the Good, (Edinburgh University Press, 2007), pp. 76-92. On 349a-354a, see my Socrates, Pleasure, and Value (Oxford University Press, 1999), pp. 97-113. 
Thrasymachus, so I cannot tell why it denies the obvious: Socrates, at every step, begins with Thrasymachus' premises in eliciting Socratic conclusions.

The book confuses the hypothetical method for unhypothetical dialectic throughout, in, for example, its discussions of Republic 2 and 5, the Phaedo, and the Gorgias. About Socrates' refutation of Polus and the conclusions reached in the Gorgias, the book says: "The argument is not the one Socrates would have chosen, but one that is forced on him by the state of Polus' thinking" (p. 159). Evidently, the book imagines that the argument Socrates would freely choose is one where the interlocutor grants to Socrates without dispute starting points of Socrates' own choosing. This is to imagine that Socrates' preferred method is, in terms of the Divided Line, the inferior hypothetical account, not the superior unhypothetical, dialectical account. Notice that a dialectician is never forced to do things in conversation but freely begins unhypothetically, with whatever is challenged in conversation, and nevertheless, always derives the same conclusion.

\section{Conclusion}

The book might both reverse its assessment of the relative value of existential versus academic questions and repent of its antidialecticism, yet nonetheless maintain its thesis that Plato's dialogues contain images of philosophical dialectic as well as other genres, all for the sake of persuading the reader to turn to a life of philosophy. But the book's Unitarian corollary about Plato's career is a lost cause, depending as it does on the claim that in dialectic, different conclusions come from different starting points - which is precisely the claim falsified by the Divided Line.

Unitarianism forces the book to interpret Socrates as "forced" (p. 159) rather than free in conversation. Unitarianism forces the book to see, instead of lucid argument, a "fog" (p. 11) of Socrates seeming to argue for contrary positions in different dialogues while in fact holding the same position throughout. The book's Unitarianism comes at an exorbitant price: Socratic conversations turn out to be, in terms of the Divided Line, inferior hypothetical persuasion rather than superior unhypothetical dialectic. The book does wrong to purchase unity at such a price. We do better to interpret Socratic conversation as superior unhypothetical dialectic. 


\begin{tabular}{|l|l|}
\hline \multicolumn{2}{|c|}{ SNP Best-set Typesetter Ltd. } \\
\hline Journal Code: PHIB & Proofreader: Elsie \\
\hline Article No: 484 & Delivery date: 28 July 2009 \\
\hline Page Extent: 8 & Copyeditor: Mara \\
\hline
\end{tabular}

\section{AUTHOR QUERY FORM}

Dear Author,

During the preparation of your manuscript for publication, the questions listed below have arisen. Please attend to these matters and return this form with your proof.

Many thanks for your assistance.

\begin{tabular}{|c|c|c|}
\hline $\begin{array}{l}\text { Query } \\
\text { References }\end{array}$ & Query & Remark \\
\hline $\mathrm{q} 2$ & $\begin{array}{l}\text { AUTHOR: Please confirm that the article title } \\
\text { is correct. }\end{array}$ & \\
\hline q3 & $\begin{array}{l}\text { AUTHOR: Please note that numbers in } \\
\text { parenthesis were formatted as page numbers. } \\
\text { Please check and confirm that the changes are } \\
\text { correct. }\end{array}$ & \\
\hline $\mathrm{q} 4$ & $\begin{array}{l}\text { AUTHOR: Please note that citations were } \\
\text { changed to footnotes as per journal style. } \\
\text { Please check and confirm this is correct. Also, } \\
\text { please provide the publisher and year of } \\
\text { publication, and confirm that the author is } \\
\text { correct for Footnote } 1 .\end{array}$ & \\
\hline q5 & $\begin{array}{l}\text { AUTHOR: Please provide the publisher and } \\
\text { year of publication, and confirm that the } \\
\text { author is correct for Footnote } 3 \text {. }\end{array}$ & \\
\hline q6 & $\begin{array}{l}\text { AUTHOR: "The less clear subdivision of the } \\
\text { intelligible . . . down to a conclusion." There } \\
\text { seems to be corrupted symbols in this } \\
\text { sentence. Please check and insert the neces- } \\
\text { sary symbols. }\end{array}$ & \\
\hline q7 & $\begin{array}{l}\text { AUTHOR: Footnote } 6 \text { has been inserted here. } \\
\text { Please check and confirm that the placement } \\
\text { and the citation are correct. }\end{array}$ & \\
\hline
\end{tabular}

